\title{
Emergency Cancer Care: inaugural editorial
}

\author{
Knox H. Todd(D
}

On behalf of our editorial board, I would like to welcome readers to Emergency Cancer Care, the first scientific journal dedicated to the interface of cancer and emergency care. Given the growing volume of oncologic emergency care research, we feel that it is the right time to establish a single journal dedicated to this emerging subdiscipline. It is my honor to serve as founding editorin-chief for this initiative, and I am pleased to be joined by an outstanding group of editorial board members, representing a broad range of clinical and research expertise (https://emergcancercare.biomedcentral.com/ about/editorial-board).

Emergency Cancer Care aims to publish and disseminate original research and timely high-quality reviews to advance the science and practice of oncologic emergency medicine. The journal will serve as an international platform to promote new knowledge and scholarly exchange between the multiple disciplines providing emergency care for those with cancer, as well as cancer survivors.

The need to increase the emergency cancer care capacity of our heath care systems stems from multiple factors. Advances in cancer diagnosis and treatment have increased life expectancy for patients, and an overall increase in life expectancy and decreasing fertility has increased the average age of the world population. The rising number of cancer care emergencies attributable to an aging population and increasing rates of survivorship will inevitably increase the demand for emergency cancer care. Toxicities arising from cancer treatments, including surgery, cytotoxic chemotherapy, radiation, and novel molecularly-targeted therapeutics, also increase the complexity of caring for these patients.

Currently, approximately $4 \%$ of all adult ED visits in the USA are for cancer-related complaints [1]. Reports from Australia, the UK, Brazil, and South Korea highlight concerns about the growing number of cancer patients and the increasing burden of urgent and emergent

Correspondence: Knox.todd@gmail.com

Editor-in-Chief, Emergency Cancer Care, Almirante Brown 3099, Chacras de Coria, 5505 Mendoza, Argentina care [2-5]. A 2017 National Health Service (UK) report emphasized the dramatic increase in ED presentations related to cancer and concomitant high rates of inpatient admissions-often associated with poor patient experience, poor coordination of care, poor communication, and fragmented patient care pathways [6].

To better understand the increasing significance of emergency cancer care research, we conducted a brief search of PubMed citations that included both of the keywords, "cancer" and "emergency," and found an approximate $350 \%$ increase in the proportion of this keyword combination among all PubMed citations over the past 20 years (Fig. 1).

Recent institutional developments presage a rapid growth in oncologic emergency medicine scholarship. In 2010, The University of Texas MD Anderson Cancer Center established the first academic department of emergency medicine (including an oncologic emergency medicine fellowship) within a comprehensive cancer center. As yet, there are only two oncologic emergency medicine fellowships in the USA; however, each of the 51 academic medical centers with NCI-designated comprehensive cancer centers also house thriving academic emergency medicine training programs, and we expect the number of oncologic emergency medicine training opportunities to expand in the coming years. In 2015, the National Cancer Institute established the Comprehensive Oncologic Emergencies Research Network (CONCERN). This multicenter network serves as an accelerator for oncologic emergency care research, as evidenced by an increasing number of oncology-emergency medicine collaborators and research studies.

In terms of developing academic careers, cancer research offers obvious advantages to emergency medicine. Consider the relative funding climates for emergency care versus cancer research. While the National Heart, Lung, and Blood Institute (NHLBI) and National Institute of Neurologic Disorders and Stroke (NINDS) have been major federal funders of past emergency care research, the proposed 2022 budget for the National

(c) The Author(s). 2022 Open Access This article is licensed under a Creative Commons Attribution 4.0 International License, which permits use, sharing, adaptation, distribution and reproduction in any medium or format, as long as you give appropriate credit to the original author(s) and the source, provide a link to the Creative Commons licence, and indicate if changes were made. The images or other third party material in this article are included in the article's Creative Commons licence, unless indicated otherwise in a credit line to the material. If material is not included in the article's Creative Commons licence and your intended use is not permitted by statutory regulation or exceeds the permitted use, you will need to obtain permission directly from the copyright holder. To view a copy of this licence, visit http://creativecommons.org/licenses/by/4.0/. 
PubMed Citation Trend for Search Terms "Cancer" AND "Emergency"

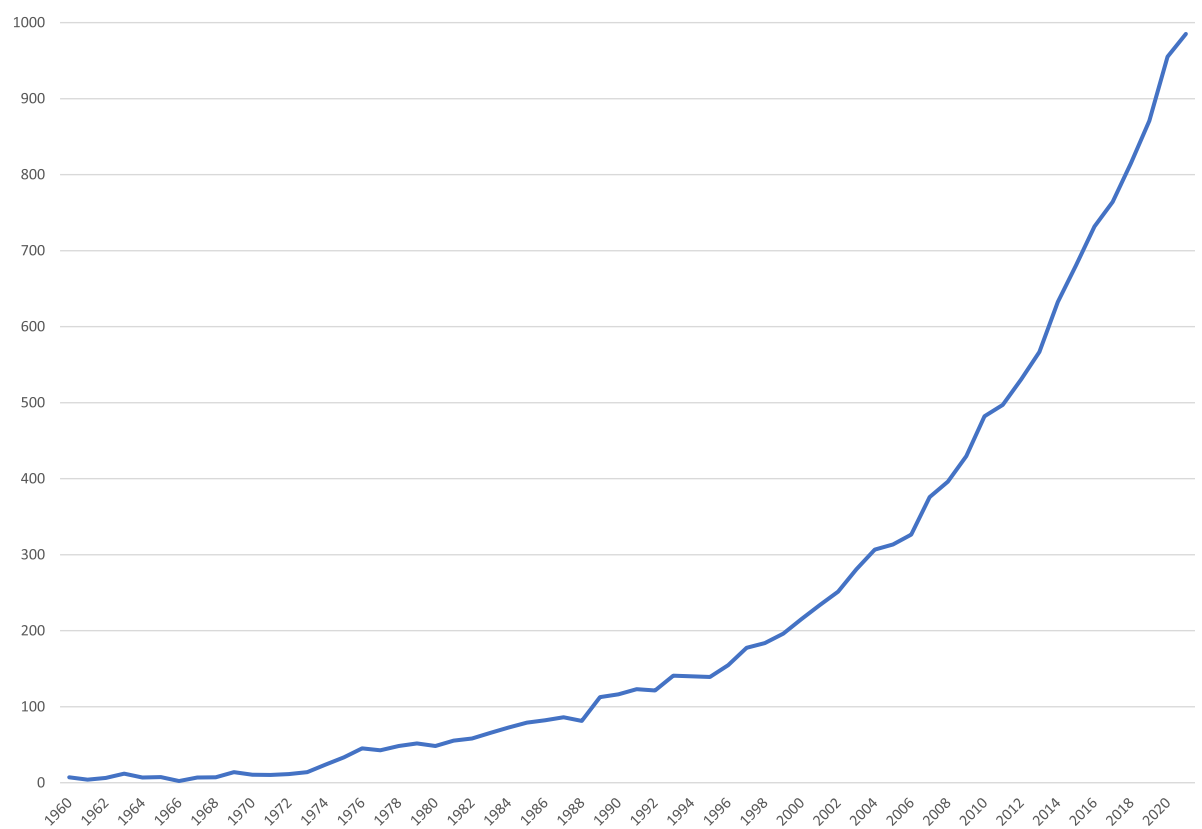

Fig. 1 Results per 100,000 PubMed citations per year. Source: PubMed by Year, http://esperr.github.io/pubmed-by-year (last accessed 16 Dec 2021)

Cancer Institute approximates that of NHLBI and NINDS combined [7]. Foundation funding is even more promising, with 260 US nonprofits providing a combined $\$ 2.2$ billion in cancer research support. This foundation funding exceeds that for heart disease, stroke, AIDS, and Alzheimer's disease combined [8].

Emergency Cancer Care will focus on the interface of oncology and emergency care; however, the journal's scope is broader than might be suggested by this seemingly narrow niche. In addition to the evaluation and treatment of oncologic emergencies, including the prevention and management of treatment toxicities (e.g., chemotoxicity, radiotoxicity, post-surgical complications, transplant-related issues), the journal will address the emergency care provider's role in primary and secondary prevention (e.g., smoking cessation, minimizing ionizing radiation, cancer screening). Although not explicitly a cancer issue, the journal will also consider contributions related to sickle cell disease. Palliative care research is an important and growing areas of emergency care research. We plan to devote a considerable portion of the journal to symptom management, end-of-life care, communications, and resource utilization.

More broadly, we hope to provide a platform for scholars exploring new models of care, informatics, operations, and quality improvement, as well as health services research and health economics. Contextually, we plan to promote scholarly work involving ethics and health disparities, curriculum development, career development, and narrative medicine.

Emergency Cancer Care is now open for submissions from authors world-wide and we will strive to provide rigorous reviews of the highest quality conducted in a timely fashion. We hope that you will join us in this effort and we greatly value your feedback.

The author receives compensation for his position as editor-in-chief of Emergency Cancer Care and declares that he has no other conflicts of interest.

\section{Acknowledgements}

Not applicable.

Author's contributions

The author read and approved the final manuscript.

Availability of data and materials Not applicable.

\section{Declarations}

Ethics approval and consent to participate Not applicable.

Consent for publication

Not applicable.

Competing interests

The author declares that he has no competing interests. 
Received: 2 December 2021 Accepted: 20 December 2021

Published online: 28 January 2022

\section{References}

1. Rivera DR, Gallicchio L, Brown J, Liu B, Kyriacou DN, Shelburne N. Trends in adult cancer-related emergency department utilization: an analysis of data from the nationwide emergency department sample. JAMA Oncol. 2017; 3(10):e172450.

2. White K, Roydhouse J, O'Riordan L, Wand T. Interventions for reducing the use of adult Emergency Department services by cancer patients: an Evidence Check rapid review brokered by the Sax Institute (http://www.sa xinstitute.org.au) for the Cancer Institute NSW, 2013.

3. Chen $\mathrm{H}$, Johnson M, Boland E, Seymour J, Macleod U. Emergency admissions and subsequent inpatient care through an emergency oncology service at a tertiary cancer centre: service users' experiences and views. Support Care Cancer. 2019;27(2):451-60.

4. Oh TK, Jo YH, Choi JW. Associated factors and costs of avoidable visits to the emergency department among cancer patients: 1-year experience in a tertiary care hospital in South Korea. Support Care Cancer. 2018;26(11): 3671-9.

5. Dufton PH, Drosdowsky A, Gerdtz MF, Krishnasamy M. Socio-demographic and disease related characteristics associated with unplanned emergency department visits by cancer patients: a retrospective cohort study. BMC Health Serv Res. 2019;19(1):647.

6. NHS England Chemotherapy Clinical Reference Group. Clinical advice to cancer alliances on commissioning of acute oncology services, including metastatic spinal cord compression. Issue/approval Oct 2017. https://www. cmcanceralliance.nhs.uk/application/files/5315/4279/3425/Clinical_Advice for_the_Provision_of_Acute_Oncology_Services_Oct_2017.pdf. Accessed 14 Aug 2020.

7. National Institutes of Health. Office of Budget. 2022 CJ Overview Volume Overall Appropriations May 28_c. Available at: https://officeofbudget.od.nih. gov/br.html. Accessed 11 Nov 2021.

8. Cuomo Ml. A World Without Cancer: The making of a new world and the real promise of prevention. New York: Rodale Books; 2012.

\section{Publisher's Note}

Springer Nature remains neutral with regard to jurisdictional claims in published maps and institutional affiliations.

Ready to submit your research? Choose BMC and benefit from:

- fast, convenient online submission

- thorough peer review by experienced researchers in your field

- rapid publication on acceptance

- support for research data, including large and complex data types

- gold Open Access which fosters wider collaboration and increased citations

- maximum visibility for your research: over $100 \mathrm{M}$ website views per year

At BMC, research is always in progress.

Learn more biomedcentral.com/submissions 